\title{
Etik Liderlik ve Materyalist Eğilimlerin Otel Çalışanlarının Kurumsal Sosyal Sorumluluk Algısına Etkisi: Alanya Örneği
}

\section{The Effect of Ethical Leadership and Materialist Tendencies on Hotel Employees' Perception of Corporate Social Responsibility: The Case of Alanya}

\author{
Dr. Öğr. Üyesi Faruk Kerem ŞENTÜRK \\ Düzce Üniversitesi \\ İşletme Fakültesi \\ E-posta: keremsenturk@duzce.edu.tr
}

Araş. Gör. Dr. Erhan BOĞAN

Adıyaman Üniversitesi

Turizm Fakültesi

E-posta: ebogan@adiyaman.edu.tr

\author{
Araş. Gör. Dr. Mehmet BAYIRLI \\ Alanya Alaaddin Keykubat Üniversitesi \\ İsletme Fakütesi \\ E-posta: mehmet.bayirli@alanya.edu.tr
}

Öz

Bu çalışma bireysel düzeyde materyalist eğilimlerin, örgütsel düzeyde ise etik liderliğin işletmenin ortaya koyduğu kurumsal sosyal sorumluluk (KSS) faaliyetlerinin algılanmasına etkisini araştırmaktadır. Araştırma evreni Alanya merkezde faaliyet gösteren 5 yıldızlı otel çalışanlarından oluşmaktadır. Evren içinden hesaplanarak örneklem alınmış ve 318 otel çalışanı üzerinde çalışma gerçekleştirilmiştir. Araştırma sonucunda elde edilen bulgulara göre etik liderlik tüm KSS boyutlarına yönelik algıyı pozitif yönde en çok etkileyen değişken iken onu başarı odaklı materyalist eğilim takip etmektedir. Mutluluk odaklı materyalist eğilimin ise çalışana ve devlete yönelik KSS algısına negatif yönde etki ettiği ortaya çıkmıştır.

Anahtar Kelimeler: Etik Liderlik, Materyalist Eğilim, Kurumsal Sosyal Sorumluluk, Otel İşletmeleri

\section{Abstract}

This study investigates the effect of materialist tendencies at the individual level and ethical leadership at the organizational level on the perception of corporate social responsibility (CSR) activities of the enterprise. The research universe consists of 5star hotel employees in the center of Alanya. A sample was taken from the universe and 318 hotel employees were included the study. According to the findings, ethical leadership is the variable that has the most positive effect on the perception towards all CSR dimensions, and followed by success-oriented materialist tendency. Happinessoriented materialist tendency has a negative impact on CSR perception for employees and the state.

Key Words: Ethical Leadership, Materialist Tendency, Corporate Social Responsibility, Hotel Businesses 


\section{Giriş}

İçinde bulunduğumuz son yüzyılda yaşanan teknolojik ve sosyolojik değişimlere bağlı olarak işletmeler çevrelerini ve sorumluluk alanlarını tekrar tanımlamak durumunda kalmışlardır. 1960'lı yıllara kadar temel sorumluluk alanı ekonomik karlılık ve hukuk kurallarına riayet etmek şeklinde algılanmaktaydı. İlerleyen yıllarda sorumluluk alanına etkileşim içinde olunan toplum, sivil toplum kuruluşları ve rakipler de dahil olmuştur. Engellilere yönelik projeler, eğitim projeleri, vakıf ve dernekler aracılığıyla desteklenen faaliyetler, sürdürülebilir çevreye yönelik projelerin yanı sıra ırkçılık ve cinsiyet ayrımına karşı gerçekleştirilen etik projeler de işletmelerin sosyal sorumluluk alanına girmiştir.

Bu sorumlulukların yerine getirilmesindeki mesuliyet tepe yönetime ait görülse de çalışanların bu konuyu nasıl algıladıkları ve gerçekleşmesi noktasında nasıl bir çaba sarf ettikleri konusu kritik bir noktadır. Liderler düşünceleri, tutumları veya davranışları ile takipçilerine yön vermekte, sorumluluk alma noktasında çalışanlarına rol model olmaktadır. Özellikle içinde bulunduğumuz tüketim ve bireysel yaşam odaklı dönemde liderlerin hal ve hareketleriyle takipçilerini etik davranışlara yönlendirmesi önem arz etmektedir. Ancak kapitalist ekonomik sistem insanları tüketime ve daha çok şeye sahip olmaya özendirmektedir. Bu özendirme sonucunda bireyler sorumluluklarını sahip oldukları maddeler aracılığıyla karşıladıklarını düşünebilmekte, maddeyi; başarı, hayatın anlamı ya da mutluluk olarak tanımlayabilmektedir.

İşletmeler çalışanlarına, devlete, topluma ve müşterilere yönelik farklı sosyal sorumluluk faaliyetleri gerçekleştirebilmektedir. Çalışanların bu tür faaliyetleri değerlendirme durumu kişisel yönelimlerine ya da yöneticilerine yönelik düşüncelerine bağlı olarak değişebilmektedir. Bu çalışmada otel çalışanlarının etik liderlik algılarının ve materyalist eğilimlerinin çalıştıkları kurumun gerçekleştirdiği sosyal sorumluluk faaliyetlerine yönelik algıları üzerindeki etkisini ortaya çıkarmak amaçlanmaktadır. İçinde bulunduğumuz dönemde insanların doğal olana yönelişi, sürdürülebilir faaliyetlere verdiği değer ve hümanist düşünceye ilgi düzeyi arttıkça KSS faaliyetlerinin önemi de artmakta ve işletmeyi diğer işletmelerden ayıran kritik bir rekabet avantajı kazanma aracına dönüşmektedir.

\section{Literatür Taraması}

\subsection{Kurumsal Sosyal Sorumluluk Kavramı}

Kurumsal sosyal sorumluluk (KSS) kavramı son 30 yıldır birçok farklı disiplinden araştırmalara konu olan bir kavramdır. Bu kavramın geçmişi her ne kadar oldukça eskilere dayansa da (Carroll, 1999), kavramın işletmeler için stratejik önemi son zamanlarda sıkça ele alınır hale gelmiştir. KSS kavramı hakkında genel kabul gören bir tanım olmamasına rağmen, Dahlsrud (2008) yaptığı araştırmada, en fazla kabul gören tanımın Avrupa Toplulukları Komisyonu (2001) ve Dünya Sürdürülebilir Kalkınma İş Konseyi (1999) tarafından yapıldığını ortaya koymuştur. Buna göre, Avrupa Toplulukları Komisyonu (2001) "işletmelerin gönülülük esasına dayalı olarak sosyal ve çevresel meselelerini, örgütsel faaliyetleriyle ve sosyal paydaşlarıyla olan etkileşimleriyle bütünleştirebildiği bir kavram" olarak tanımlarken, Dünya Sürdürülebilir Kalkınma İş Konseyi (1999) "İşletmelerin sürdürülebilir ekonomik kalkınmaya katkıda bulunma taahhüdü altında çalışanların, ailelerinin, yerel toplulukların ve geniş çapta toplumun yaşam kalitesini iyileştirmek için çalışması" olarak tanımlamıştır. KSS kavramının gelişimine önemli katkı sağlayan Carroll (1979) geliştirmiş olduğu piramitle, işletmelerin sosyal sorumluluklarını sırasıyla ekonomik, yasal, ahlaki ve gönüllü sorumluluk olarak ele almıştır. Buna göre; ekonomik sorumluluk, işletmenin mal ve 
hizmet üretip, bunları satıp kar elde etmesi olan temel sorumluluğunu; yasal sorumluluk, işletmenin faaliyetlerini gerçekleştirirken yasal düzenlemelere uymasını; ahlaki sorumluluk, yasalarda yer almayan ancak paydaşlar tarafından genel kabul gören normlar, standartlar ve beklentilere uygun hareket edilmesini ve son olarak gönüllü sorumluluk ise, işletmeyi iyi bir kurumsal vatandaş olarak öne çıkaran, toplum yararına yapılan vicdani sorumlulukları ifade etmektedir (Carroll, 1979; 1991). KSS aynı zamanda, teknik KSS ve geleneksel KSS olarak iki boyut altında da ele alınmaktadır (Mattingly ve Berman, 2006; Godfrey ve diğ., 2009; Du ve diğ., 2013). Teknik KSS, işletmenin çalışanlar, müşteriler, yatırımcılar gibi birincil paydaşlarına yönelik kaliteli mal ve hizmet sunmak, eğitim ve terfi olanakları sunmak, hissedarların kar payını artırmak gibi sosyal sorumluluklarını ifade ederken; geleneksel (instutional) KSS işletmenin toplum, doğal çevre gibi ikincil paydaşlarına yönelik toplumun yaşam kalitesini arttırıcı girişimlerde bulunmak, atık azaltımı, enerji ve su tasarrufu gibi sosyal sorumluluklarını ifade etmektedir (Du ve diğ., 2013).

Turizm işletmeleri tarafından gerçekleştirilen sosyal sorumluluk uygulamalarının işletmelere sağladığı stratejik faydalar konusunda birçok çalışma bulunmaktadır. Bu çalışmalar genel olarak işletme performansı (Kang ve diğ., 2010; Lee ve diğ., 2013; Lee ve diğ., 2013; Youn ve diğ., 2015), çalışan tutum ve davranışları (Fu ve diğ., 2014; Zientara ve diğ., 2015; Kim ve diğ., 2016; Kim ve diğ., 2017), müşteri tutum ve davranışları (Küçükusta ve diğ., 2013; Siu ve diğ., 2014; Kim ve Ham, 2016), potansiyel kalifiye elemanlardan alınan geri dönüşler (Boğan ve Dedeoğlu, 2017) üzerinde yoğunlaşmaktadır.

KSS'nin belirtilen stratejik önemine rağmen, işletmelerin sosyal sorumluluk performansının nasıl ölçüleceğine dair literatürde genel kabul gören bir ölçüm aracı mevcut değildir. KSS'nin içeriği ve yönü yapılan araştırmalarda oldukça farklılık göstermektedir (Rupp ve Mallory, 2015). Ancak buna rağmen, literatürde genel olarak KSS kavramı Carroll (1979) tarafından ortaya konulan piramidin boyutları olan ekonomik, yasal, ahlaki ve gönüllü sorumluluk (Çalışkan ve Ünüsan, 2011; Fu ve diğ., 2014; Wang, 2014; Kim ve diğ., 2016; Kim ve diğ., 2017); Freeman (1984) tarafından geliştirilen paydaş kuramı (Türker, 2009; Küçükusta ve diğ., 2013; Farooq ve diğ., 2014; Park ve Levy, 2014; Boğan ve diğ., 2016) ve sürdürülebilir kalkınmanın ekonomik, sosyal ve çevresel olmak üzere temel teşkil eden üç boyutu ile ölçülmektedir (Cowper-Smith ve De Grosbois, 2011; Martinez ve diğ., 2013).

\subsection{Etik Liderlik}

Son yıllarda dünyanın önde gelen şirketlerinde yaşanan yolsuzluk, aldatma, adaletsizlik ve benzeri davranışlar firmaların uzun vadeli çıkarlarını negatif şekilde etkilemiştir. Buna bağlı olarak liderliğin işletme içinde etik davranışları oluşturmadaki rolü sorgulanmaya başlamıştır. Firmaların kısa vadeli çıkarcı düşüncelerden sıyrılarak uzun vadeli başarılarını garanti altına almaları ve demokrasinin devamlılığı için kurumsal liderlerin, takipçilerinin güvenini ve sadakatini ve toplumun saygısını, ahlaki davranışlar (temel olarak iyi olarak tanımlanabilecek davranışlar) yoluyla kazanmaları gerekmektedir (Aranson, 2001: 245).

Etik, ister bireysel olarak isterse de bir organizasyonda olsun, kişisel tercihler ve davranış standartlarıyla ilgilidir (Conaway ve Fernandez, 2000: 26). Sosyal öğrenme teorisi kapsamında liderliği ele alan Brown ve arkadaşlarına (2005: 120) göre "kişisel faaliyetlerinde ve kişilerarası ilişkilerinde normatif olarak uygun faaliyetler sergileyen ve sergilemiş olduğu bu tarz faaliyetleri artırmayı hedefleyen, bunu yaparken de iki yönlü iletişim, güçlendirme ve etkin düşünme yöntemlerini kullanan liderlik tarzı" etik liderlik 
olarak tanımlanmaktadır. Piccolo ve arkadaşları (2010) ise kişisel eylemler yoluyla normatif olarak uygun davranışın gösterilmesi ve kişilerarası ilişkiler ve iki yönlü iletişim, güçlendirme ve karar verme yoluyla bu tür davranışların takipçilere tanıtımı şeklinde etik liderliği ele almaktadır.

Trevino ve diğerleri (2000) etik bir liderin çalışanları üzerindeki etik lider itibarını artırması gerektiğini, bununda bireyin hem ahlaki bir kişilik olarak hem de ahlaki bir yönetici olarak takipçileri üzerinde güçlü bir algı oluşturması yoluyla olacağını belirtmektedir. Van den Akker ve diğerleri (2009) araştırmaları sonucunda çalışanların etik davranışlar sergileyen liderlere güven düzeylerinin yüksek olduğunu belirtmektedir. Etik liderlik, ahlakı proaktif bir şekilde yönetir ve bir liderin astları etkileme ve etik davranışlarını yönetme, etik standartları iletme ve etik olmayan davranışlar sergileyen çalışanları disiplin altına alma gibi çabalarını ifade eder (Engelbrecht ve diğ., 2017).

Lin ve Liu'nun (2017) yaptığı çalışmaya göre etik liderlik davranışları KSS algısı ile pozitif yönde ilişkili olmakla birlikte KSS ile işe adanmışlık arasındaki ilişki de moderatör bir etkiye de sahiptir. Dolayısıyla etik liderlik davranışlarının gerek kurum içinde gerek kurum dışına yönelik sosyal sorumluluk algısına pozitif etkileri olacağı düşünülmektedir. Brammer ve arkadaşları (2007) da çalışan eğitimleri, devamlı eğitim programları, güvenli çalışma ortamı, çeşitlilik politikaları, gündüz bakım programları ve etik çalışma uygulamaları gibi faaliyetlerin içsel KSS kapsamında ele alınması gerektiğini vurgulamaktadır. Lawton ve Paez (2014) etik liderlerin, paydaşların çeşitli intiyaçlarını herkesin çıkarlarına hizmet edecek şekilde dengelemeye çalıştıklarını ve bu nedenle genellikle KSS lideri olarak da görüldüklerini belirtmektedir. De Roeck ve Farooq (2018) ise çalışanların KSS algılarının etik liderlik algıları ile tutarlı olduğunu, bu tip liderlik ilişkilerinin çalışanların sosyal faydada bulunma eğilimlerini artırdığını belirtmektedir.

\subsection{Materyalist Eğilim}

Materyalizm, varlık açısından temel unsur olarak maddeyi görür. Materyalizme göre madde, cansız, hareketsiz bir şey olmayıp, tam tersine aktif oluşundan dolayı evrendeki sürekli olgunun yegâne sebebidir (Yüce, 2009). Materyalizm, Türk Dil Kurumuna göre "Maddecilik" olarak adlandırımakta ve "1. Para, mal vb. ne çok önem verme. 2. Dünyada, yalnızca maddenin varlığını kabul eden, Tanrı, ruh vb. manevi kavramları ret ve inkâr eden felsefi görüş" şeklinde tanımlanmaktadır (TDK, 18.09.2017). Belk (1984) materyalizmi bir tüketicinin dünyevi eşyalara verdiği önem olarak tanımlarken, Çopur (2011) bir tüketicinin maddi nesnelerin elde edilmesi ve sahip olunmasına yönelik geliştirdiği değer algısı şeklinde tanımlamaktadır.

Materyalizm ne kadar modern dünyanın geliştirdiği bir yaşam felsefesi olarak görülse de insan açısından sahip olma arzusunun çok daha eski dönemlere dayandığı bilinmektedir (McKendrick ve diğ., 1982). Materyalist düşüncenin kaynağı konumundaki Kapitalizm yalnızca temel ya da gerçek intiyaçların karşılanmasına yönelik tüketim mallarını (ve hizmetlerini) değil, oldukça farklı türdeki intiyaçların giderilmesine yönelik malları da sunmaktadır. Esasen, tarihsel açıdan düşünüldüğünde giderek artan üretkenliğin belirgin bir sonucu olarak "arzular" "istekler"e, istekler de "ihtiyaç"lara dönüşmüş ve mallar farklı kullanımlara sahip hale gelmiştir. Benzer bir şekilde lüks kabul edilen mallar gerekli mallara, gerekli oldukları düşünülen mallar da standart intiyaçlara dönüşmüştür (Yanıklar, 2010: 26). Reel gelir düzeyinin artışı ve tüketim ürünlerindeki bolluk materyalizmi mümkün hatta kaçınılmaz hale getirmiştir (Belk, 1985). Günümüzde materyalizm, ihtiyaç duyulmadığı halde aşırı satın alma 
isteği ya da lüks tüketim mallarını elde etme arzusu ile kendini göstermektedir (Quadır, 2012).

Materyalizmin nedenleri, sonuçları, materyalistlerin karakteristikleri ve davranışları, ahlaki düşünce yapısı ile ilişkileri açısından birçok araştırma gerçekleştirilmiştir (Brook, 2013; Ahuvia ve Wong, 2002; Hirsh ve Dolderman, 2007, Belk, 1983). Araştırma kapsamında Richins ve Dawson'ın (1992) perspektifiyle materyalizm; maddeyi hayatın merkezine koyma, mutluluğun kaynağı olarak görme ve başarı olarak algılama açısından değerlendirilmektedir. Materyalist yaşantıyı benimsemiş insanlar kendilerini ve başkalarını, sahip oldukları eşyalar ve imkanlar dahilinde tanımlayıp mutluluğu tüketim yapmaya bağlamaktadırlar (Mckeage, ve diğ., 1993). Watson'a (2003: 724) göre materyalist kişiler yaşamlarını harcama odaklı ve borçlanma eğilimine daha yatkın halde geçirmektedir.

Materyalizmi benimseyen bireyler kazanımlarını ve mülklerini hayatının merkezine koymakta, yaşamına bu bağlamda anlam katmakta ve bireysel gündelik amaçlar vermektedir (Richins, 2004). Materyalistlerin yaşamlarının merkezine maddeyi ve bunun edinilmesini koymasının temel nedenlerinden biri bunun yaşam refahı ve memnuniyeti sağlamasıdır. Pek çok insan mutluluğu, kişisel ilişkiler, deneyimler ve başarılarda bulabilirken, bu bireyler için bütün bunlar yeteri ölçüde önem arz etmez. Onlara göre, herkesin yaşam tatmini sahip oldukları varlıklarla yakından ilişkilidir (Doğan, 2010).

Materyalist düşünceye sahip bireylerin kendi başarıları ya da diğerlerinin başarıları elde edilen maddi varlıkların sayısı ve kalitesine bağlıdır (Richins ve Dawson, 1992). Arzulanan imajı yansıtan ürünlere sahip oldukça kendilerini başarılı addeden bu bireyler için sahip olduklarının maliyeti, sağladıkları tatminden daha önemlidir. Dahası, maddi varlık sahipliği başarının en önemli göstergesi iken doğru düşünmenin de ispatı olarak görülmektedir (Doğan, 2010).

\section{Yöntem}

\subsection{Evren ve Örneklem}

Araştırma evreni olarak Antalya ili Alanya ilçe merkezinde bulunan Turizm Bakanlığı İşletme Belgeli 5 yıldızlı otel işletmeleri belirlenmiştir. Alanya Ekonomik Raporu 2016'ya (2017) göre ilgili yılda Alanya merkezinde Turizm İşletme Belgeli 5 adet 5 yıldızlı otel bulunmaktadır. Otellerde çalışan personel bilgisine ulaşılamadığı için evren sayısı yatak sayısı toplamı ve yatak başına düşen personel sayısı üzerinden hesaplanmıştır. Rapordan elde edilen verilere göre ilgili yılda bahsi geçen 5 otelin yatak sayısı toplamı 2428 olarak hesaplanmaktadır. Literatürde genel olarak farklı çalışmalarda 5 yıldızlı otellerde yatak başına düşen personel sayısı olarak (Sevin ve Küçük, 2016; Özdemir, 2015; Çakmakçı, 2012; Pelit ve Öztürk, 2010) Erdem'in (2004) çalışmasına atıfta bulunarak 0,59 sayısı kullanılmaktadır. Buna göre $2428^{*} 0,59$ üzerinden evren sayımız 1433 olarak hesaplanmaktadır.

Evreni temsil edecek örneklem sayısını tespit etmek amacıyla " $n=N . t^{2}$.p.q / d2.(N-1)+t².p.q" formülü uygulanmıştır (Yazıcıoğlu ve Erdoğan, 2007: 70). Formülde ilgili rakamlar yerine konulduğunda örneklem sayısının 304 olarak hesaplandığı tespit edilmiştir. Çalışmada kolayda örnekleme yöntemiyle toplam 346 anket toplanmıştır. Toplanan anketlerin 28'i eksik veri nedeniyle analizlere dahil edilmemiştir ve analizler 318 anket ile gerçekleştirilmiştir. 


\subsection{Veri Toplama Tekniği}

Araştırmada nicel yöntem tercih edilmiştir. Veriler anketler aracılığıyla toplanmıştır. Araştırma sürecinde kullanılan ölçekler ile ilgili detaylı bilgiler aşağıda paylaşılmaktadır.

\subsubsection{Araştırmada Kullanılan Ölçekler}

KSS Ölçeği: Ölçek Türker (2006) tarafından ilk olarak 7 boyut ve 18 ifade olarak geliştirilmiştir. Türker (2009) yılında çalışmalarında aynı ölçeği 4 boyut (çalışanları, müşteriler, devlet ve toplum) ve 17 ifadeye indirerek sadeleştirmiştir. Boyutların Cronbach Alfa skorları 0,85 ila 0,92 arasında değişmektedir.

Materyalizm Ölçeği: Ölçek Richins ve Dawson (1992) tarafından ilk olarak 3 boyut ve 18 ifade olarak geliştirilmiştir. Richins (2004) yılında ölçeğin 3 boyutunun 18, 15, 9, 6 ve 3 ifadeli farklı yapılarla temsil edilme durumunu tekrar değerlendirmiş ve ölçeğin sadeleştirilmiş halinin de geçerliliğini ortaya koymuştur. Araştırmada 3 boyutlu 9 ifadelik ölçek kullanılmıştır. Çalışmada kullanılan söz konusu ölçeğin Türkçeye uyarlanması Doğan (2010) tarafından gerçekleştirilmiştir ve ölçek 0,84'lük Cronbach Alfa skoruna sahiptir.

Etik Liderlik Ölçeği: Brown ve diğerlerinin (2005) geliştirmiş olduğu etik liderlik ölçeğinin Türkçeye uyarlanması güvenilirlik ve geçerlilik analizi Çelik ve arkadaşları (2015) tarafından gerçekleştirilmiştir. Tek boyutlu olan ölçek 10 ifadeden oluşmaktadır. Ölçeğin güvenilirlik analizi Cronbach Alfa katsayısı Brown ve arkadaşları (2005) tarafından 0,92 ve Çelik ve arkadaşları (2015) tarafından 0,94 olarak tespit edilmiştir.

\subsection{Araştırma Modeli ve Hipotezler}

Yapılan literatür taraması sonucunda bağımlı değişken olan KSS ve dört alt değişkeni ile bağımsız değişkenler olan etik liderlik ve üç alt değişkenli materyalist eğilim arasındaki ilişkiler aşağıdaki modelde paylaşılmaktadır.

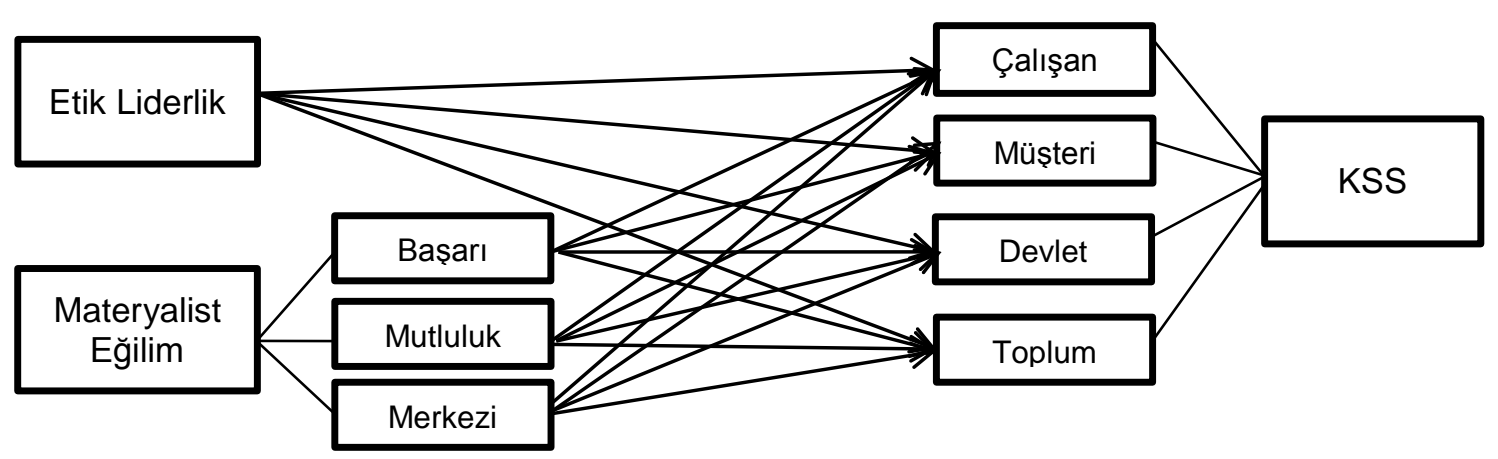

Şekil 1: Araştırma Modeli

Literatürde etik liderlik davranışlarının SS ve KSS algısına pozitif yönde etki ettiğini belirten çalışmalar bulunmaktadır (Lin ve Liu, 2017; Brammer ve arkadaşları, 2007; Lawton ve Paez, 2014; De Roeck ve Farooq, 2018). Çalışanlarının fikirlerini dinleyen, etik standartlara dikkat ederek bu kuralların işletme içinde yayılmasına çaba sarfeden, gerek iş gerek kişisel hayatı ile rol model olan, adil ve güvenilir kararlar 
verebilen bir liderin işletmenin gerçekleştirdiği sosyal sorumluluk faaliyetlerine yönelik algıyı pozitif yönde etkileyebileceği öngörülerek hipotez aşağıdaki şekilde kurgulanmıştır.

H1: Etik liderlik davranışları çalışanların işletmelerine yönelik KSS algısını etkilemektedir.

$\mathrm{H} 1_{\mathrm{a}}$ : Etik liderlik davranışları işletmenin çalışanlarına yönelik gerçekleştirdiği sosyal sorumluluk faaliyetleri algısını pozitif yönde etkiler.

$\mathrm{H} 1_{\mathrm{b}}$ : Etik liderlik davranışları işletmenin müşterilerine yönelik gerçekleştirdiği sosyal sorumluluk faaliyetleri algısını pozitif yönde etkiler.

$\mathrm{H} 1_{\mathrm{c}}$ : Etik liderlik davranışları işletmenin devlete yönelik gerçekleştirdiği sosyal sorumluluk faaliyetleri algısını pozitif yönde etkiler.

$\mathrm{H} 1_{\mathrm{d}}$ : Etik liderlik davranışları işletmenin topluma yönelik gerçekleştirdiği sosyal sorumluluk faaliyetleri algısını pozitif yönde etkiler.

Giacalone ve arkadaşları (2008) materyalist algıdaki artışın bireyin çalıştığı işletmeyi koruma ve destekleme algısını düşürdüğünü belirtmektedir. Muncy ve Eastman (1998) ise materyalist eğilim artışının bireyin kendi hayatına odaklanmasını sağladığı için başkaları için endişe etmeme veya etik dışı davranma eğilimine de pozitif etki ettiğini belirtmektedir. Kolodinsky ve arkadaşları (2010) ise materyalist eğilimin KSS algısını negatif yönde etkilediğini belirtmektedir. Giacalone ve Thompson (2006) ise işletmeyi temele alan dünya görüşüne göre materyalist düşüncenin ve kişisel çıkarların karar alma süreçlerine dahil edilmesinin uygun olduğunu belirtmektedir. Dolayısıyla literatüre göre materyalist eğilim algısının KSS algısına pozitif ve negatif etkileri olduğu belirtilebilir. Materyalist bir yaşam tarzını tercih eden bireyler maddeyi hayatın merkezine koyma, mutluluğu veya başarıyı elde edilen maddi kazanımlar üzerinden değerlendirme eğilimi göstermektedir. Bu bağlamda hayatının merkezine materyalist bir bakış açısını koymuş bireylerin, çalıştığı kurumun sosyal sorumluluk faaliyetlerine yönelik negatif bir algı geliştirebilecekleri düşünülürken, başarıyı maddi unsurlarla tanımlayan bir bireyin işletmesinin başarılarını, adının duyulmasını, marka bir işletmede çalışmasına katkı sağlaması açısından sosyal sorumluluk faaliyetlerine yönelik pozitif bir algı geliştireceği düşünülmektedir. Bu bağlamda hipotez aşağıdaki şekilde kurgulanmıştır;

H2: Çalışanların maddeyi başarı olarak görmek eğilimleri KSS algısını etkilemektedir.

$\mathrm{H} 2 \mathrm{a}$ : Çalışanların maddeyi başarı olarak görme eğilimi işletmenin çalışanlarına yönelik gerçekleştirdiği sosyal sorumluluk faaliyetleri algısını pozitif yönde etkiler.

$\mathrm{H} 2_{\mathrm{b}}$ : Çalışanların maddeyi başarı olarak görme eğilimi işletmenin müşterilerine yönelik gerçekleştirdiği sosyal sorumluluk faaliyetleri algısını pozitif yönde etkiler.

$\mathrm{H} 2_{\mathrm{c}}$ : Çalışanların maddeyi başarı olarak görme eğilimi işletmenin devlete yönelik gerçekleştirdiği sosyal sorumluluk faaliyetleri algısını pozitif yönde etkiler.

$\mathrm{H} 2_{\mathrm{d}}$ : Çalışanların maddeyi başarı olarak görme eğilimi işletmenin topluma yönelik gerçekleştirdiği sosyal sorumluluk faaliyetleri algısını pozitif yönde etkiler. 
H3: Çalışanların maddeyi hayatın merkezine koyma eğilimi KSS algısını etkilemektedir.

$\mathrm{H}_{\mathrm{a}}$ : Çalışanların maddeyi hayatın merkezine koyma eğilimi işletmenin çalışanlarına yönelik gerçekleştirdiği sosyal sorumluluk faaliyetleri algısını negatif yönde etkiler.

$\mathrm{H}_{\mathrm{b}}$ : Çalışanların maddeyi hayatın merkezine koyma eğilimi işletmenin müşterilerine yönelik gerçekleştirdiği sosyal sorumluluk faaliyetleri algısını negatif yönde etkiler.

$\mathrm{H}_{\mathrm{c}}$ : Çalışanların maddeyi hayatın merkezine koyma eğilimi işletmenin devlete yönelik gerçekleştirdiği sosyal sorumluluk faaliyetleri algısını negatif yönde etkiler.

$\mathrm{H} 3_{\mathrm{d}}$ : Çalışanların maddeyi hayatın merkezine koyma eğilimi işletmenin topluma yönelik gerçekleştirdiği sosyal sorumluluk faaliyetleri algısını negatif yönde etkiler.

H4: Çalışanların maddi unsurlara sahip olmayı mutluluk kaynağı olarak görme eğilimi KSS algısını etkilemektedir.

$\mathrm{H} 4_{\mathrm{a}}$ : Çalışanların maddi unsurlara sahip olmayı mutluluk kaynağı olarak görme eğilimi işletmenin çalışanlarına yönelik gerçekleştirdiği sosyal sorumluluk faaliyetleri algısını negatif yönde etkiler.

$\mathrm{H} 4_{\mathrm{b}}$ : Çalışanların maddi unsurlara sahip olmayı mutluluk kaynağı olarak görme eğilimi işletmenin müşterilerine yönelik gerçekleştirdiği sosyal sorumluluk faaliyetleri algısını negatif yönde etkiler.

$\mathrm{H} 4_{\mathrm{c}}$ : Çalışanların maddi unsurlara sahip olmayı mutluluk kaynağı olarak görme eğilimi işletmenin devlete yönelik gerçekleştirdiği sosyal sorumluluk faaliyetleri algısını negatif yönde etkiler.

$\mathrm{H} 44_{\mathrm{d}}$ : Çalışanların maddi unsurlara sahip olmayı mutluluk kaynağı olarak görme eğilimi işletmenin topluma yönelik gerçekleştirdiği sosyal sorumluluk faaliyetleri algısını negatif yönde etkiler.

\subsection{Araştırmanın Sınırlılıkları}

Araştırma kavramsal olarak KSS algısını açıklayıcı birçok unsur olması bakımından ele aldığı değişkenlerle sınırlıdır. Turizm sektöründe yapısı, büyüklüğü, hizmet verdiği müşteri kitlesine göre birçok sınıfa ayrılan turizm işletmeleri açısından otel işletmeleri ve otel işletmeleri sınıflandırmasında beş yıldızlı otel işletmeleri çalışanları ile sınırlıdır. Verilerin toplanma süreci 2016 yılı Nisan-Eylül ayları aralığında sınırlıdır. Ayrıca Türkiye'nin sahip olduğu birçok turistik destinasyon arasında uygulama alanı olarak Alanya ilçe merkezi ile sınırıdır.

\section{Bulgular}

\subsection{Demografik Bulgular}

Araştırmaya dahil olan katılımcıların cinsiyet dağılımlarına bakıldığında çoğunluğun (\%62) erkek olduğu, yarısından fazlasının (\%60) bekar olduğu, eğitim seviyelerine bakıldığında ilköğretim (\%23) ve lise (\%43) seviyesinde yoğunlaştığı tespit edilmiştir. 
Çalışılan departmanlara göre dağılıma bakıldığında her departmandan katıım olmakla birlikte kat hizmetleri (\%16), mutfak (\%17), yiyecek içecek (\%14) ve önbüro (\%9) çalışanlarının yoğunlukta olduğu tespit edilmiştir.

\subsection{Betimsel Analizlere Yönelik Bulgular}

Araştırma kapsamında kullanılan değişkenlere yönelik ortalama, standart sapma, güvenilirlik katsayıları ve soru sayılarına ait istatistikler tablo 1 'de paylaşılmaktadır.

Tablo 1: Değişkenler İle İIgili Tanımlayıcı İstatistikler

\begin{tabular}{|l|c|c|c|c|c|}
\hline Yapılar & Değişkenler & Ortalama & $\begin{array}{l}\text { Standart } \\
\text { Sapma }\end{array}$ & $\begin{array}{l}\text { Soru } \\
\text { Sayısı }\end{array}$ & $\begin{array}{l}\text { Cronbach Alfa } \\
\text { Katsayısı }\end{array}$ \\
\hline \multirow{3}{*}{$\begin{array}{l}\text { Kurumsal } \\
\text { Sorumluluk }\end{array}$} & Çalışan & 3,71 & 1,08 & 5 & 0,91 \\
\cline { 2 - 6 } & Müşteri & 3,86 & 0,99 & 3 & 0,85 \\
\hline \multirow{3}{*}{ Materyalist Eğilim } & Devlet & 3,96 & 0,94 & 2 & 0,77 \\
\cline { 2 - 6 } & Toplum & 3,73 & 0,92 & 7 & 0,91 \\
\hline Etik Liderlik & Başarı & 3,39 & 1,25 & 3 & 0,87 \\
\cline { 2 - 6 } & Merkezi & 3,13 & 0,67 & 2 & 0,79 \\
\cline { 2 - 6 } & Mutluluk & 3,54 & 1,05 & 3 & 0,83 \\
\hline & & 3,67 & 0,95 & 10 & 0,93 \\
\hline
\end{tabular}

Değişkenlere yönelik tanımlayıcı istatistikler incelendiğinde katılımcıların çalıştıkları kurumun sosyal sorumluluk faaliyetlerinden özellikle devlete yönelik gerçekleştirilen sorumluluk faaliyetlerini $(\bar{X}=3,96)$ diğerlerine kıyasla daha yüksek düzeyde algıladıkları görülmektedir. Katılımcıların materyalist eğilimleri değerlendirildiğinde ise ortalamanın üstünde maddi unsurlara değer verdikleri ve özellikle maddi unsurlarla mutluluğun yaşanacağı düşüncesi $(\bar{X}=3,54)$ diğerlerine kıyasla ön plana çıkmaktadır. Çalışanların etik liderlik algısının ise ortalama düzeyde olduğu söylenebilir. Alfa katsayısı için kabul edilebilir bir değerin en az 0.70 olması arzu edilir. Ancak inceleme türü çalışmalarda bu değerin 0.50 'e kadar makul kabul edilebileceği de bazı araştırmacılarca öngörülmektedir (Altunışık, 2007, s.116). Buna göre .77 ila .93 arasında değişen katsayıların güvenilir düzeyde olduğu söylenebilir.

\subsection{Hipotezlere Yönelik Bulgular}

Bu kısımda araştırma modelinde ortaya konulan hipotezleri test etmek amacıyla çoklu regresyon analizinden faydalanılmaktadır. Regresyon analizinin ön koşullarından biri verilerin normal dağılım göstermesidir. Bu bağlamda çarpıklık ve basıklık değerlerinin 2 ve +2 arasında olması nedeniyle (George ve Mallery, 2010) veriler normal dağılmaktadır. Diğer bir önkoşul ise otokorelasyon olmamasıdır ki elde edilen Durbin Watson değerlerinin 1,5 ila 2,5 arasında olması (Küçüksille, 2010) nedeniyle bahsi geçen koşulun sağlandığı belirtilebilir.

Tablo 2: Çalışana Yönelik KSS Algısına Etki Eden Değişkenler

\begin{tabular}{|l|l|l|l|l|l|l|l|l|l|}
\hline Değişkenler & $\mathbf{B}$ & $\begin{array}{l}\text { Standart } \\
\text { Hata }_{\mathbf{B}}\end{array}$ & $\boldsymbol{\beta}$ & $\mathbf{t}$ & $\mathbf{p}$ & $\mathbf{\text { Íkili r }}$ & $\begin{array}{l}\text { Kısmi } \\
\mathbf{r}\end{array}$ & Tol. & VIF \\
\hline (Sabit) &, 403 &, 150 & - & 2,690 &, 008 & - & - & - & - \\
\hline MATBaşarı &, 274 &, 041 &, 317 & 6,750 &, 000 &, 584 &, 356 &, 442 & 2,263 \\
\hline MATMerkezi &, 018 &, 048 &, 019 &, 375 &, 708 &, 414 &, 021 &, 399 & 2,509 \\
\hline MATMutluluk &,- 197 &, 051 &,- 192 & $-3,844$ &, 000 &, 383 &,- 212 &, 390 & 2,565 \\
\hline Etik Lider &, 819 &, 043 &, 717 & 18,974 &, 000 &, 802 &, 731 &, 683 & 1,464 \\
\hline R=0,833R ${ }^{2}=0,690 \mathrm{~F}=177,807 \mathrm{p}=0,000$ Durbin-Watson $=1,700$ \\
\hline
\end{tabular}


Bağımsız değişkenler ile bağımlı değişken arasındaki ikili korelasyonlar incelendiğinde, materyalist eğilim alt boyutları ile pozitif ve orta düzeyde ilişkilerin $(r=, 58,41,38)$ ve etik liderlik ile pozitif yüksek düzeyde $(r=, 80)$ bir ilişkinin olduğu görülmektedir. Diğer değişkenler kontrol edildiğinde ise tüm korelasyon katsayılarının düştüğü hatta materyalist eğilimin mutluluk alt boyutunun negatife dönüştüğü görülmektedir. Yine VIF değerleri arasında 10'dan yüksek bir değer ve tolerance değerleri arasında 0.20 'den düşük bir değer olmaması bağımsız değişkenler arasında çoklu bağlantılııı̆ın olmadığını göstermektedir. Ayrıca Durbin-Watson katsayısı $(1,700)$ bağımsız değişkenler ile hata terimleri arasında sorunlu bir ilişkinin olmadığını göstermektedir.

Tabloda yer alan bulgulara göre bağımsız değişkenlerin, bağımlı değişkeni açıklama düzeyi istatistiksel açıdan anlamlıdır ( $\left.R^{2}=, 690 \quad F=177,807 \quad p=, 000\right)$. Standardize edilmiş regresyon katsayılarına $(\beta)$ göre, bağımsız değişkenlerin bağımlı değişken üzerindeki göreceli önem sırası; etik lider, başarı, mutluluk ve merkezi şeklindedir. Regresyon katsayılarının anlamlılığına dair t-testi sonuçları incelendiğinde ise, materyalist eğilim alt boyutlarından başarı çalışana yönelik KSS algısını pozitif yönde etkilerken, mutluluk negatif yönde etkilemekte ve merkeziliğin ise anlamlı bir etkiye sahip olmadığı görülmektedir. Etik liderlik algısının ise çalışana yönelik KSS algısını pozitif yönde etkilediği tespit edilmiştir. Bu bilgiler doğrultusunda "H1 $1_{\mathrm{a}}$ : Etik liderlik davranışları işletmenin çalışanlarına yönelik gerçekleştirdiği sosyal sorumluluk faaliyetleri algısını pozitif yönde etkiler", "H2 görme eğilimi işletmenin çalışanlarına yönelik gerçekleştirdiği sosyal sorumluluk faaliyetleri algısını pozitif yönde etkiler" ve "H4a: Çalışanların maddi unsurlara sahip olmayı mutluluk kaynağı olarak görme eğilimi işletmenin çalışanlarına yönelik gerçekleştirdiği sosyal sorumluluk faaliyetleri algısını negatif yönde etkiler" hipotezleri kabul edilirken " $\mathrm{H} 3_{\mathrm{a}}$ : Çalışanların maddeyi hayatın merkezine koyma eğilimi işletmenin çalışanlarına yönelik gerçekleştirdiği sosyal sorumluluk faaliyetleri algısını negatif yönde etkiler" hipotezi reddedilmiştir.

Tablo 3: Müşteriye Yönelik KSS Algısına Etki Eden Değişkenler

\begin{tabular}{|c|c|c|c|c|c|c|c|c|c|}
\hline Değişkenler & B & $\begin{array}{l}\text { Standart } \\
\text { Hata }_{B}\end{array}$ & $\beta$ & $t$ & $\mathbf{p}$ & Íkili r & $\begin{array}{l}\text { KIsmi } \\
\mathrm{r}\end{array}$ & Tol. & VIF \\
\hline (Sabit) & 1,188 & .174 & - & 6,835 & 000 & - & - & - & - \\
\hline MATBaşarı & 097 & ,047 & 123 & 2,061 & 040 & 433 & 116 &, 442 & 2,263 \\
\hline MATMerkezi &, 036 &, 056 & ,041 & ,647 &, 518 & ,342 & ,037 & ,399 & 2,509 \\
\hline MATMutluluk &,- 112 & 0,60 &,- 120 & $\begin{array}{l}-1,884 \\
\end{array}$ &, 060 & ,323 &,- 106 & ,390 & 2,565 \\
\hline Etik Lider &, 710 &, 050 & ,680 & 14,178 &, 000 & ,706 & ,625 & ,683 & 1,464 \\
\hline
\end{tabular}

Bağımsız değişkenler ile bağımlı değişken arasındaki ikili korelasyonlar incelendiğinde, materyalist eğilim alt boyutları ile pozitif ve orta düzeyde ilişkilerin $(r=, 43,34,32)$ ve etik liderlik ile pozitif yüksek düzeyde $(r=, 70)$ bir ilişkinin olduğu görülmektedir. Diğer değişkenler kontrol edildiğinde ise tüm korelasyon katsayılarının düştüğü hatta materyalist eğilimin mutluluk alt boyutunun negatife dönüştüğü görülmektedir. Yine VIF değerleri arasında 10'dan yüksek bir değer ve tolerance değerleri arasında 0.20 'den düşük bir değer olmaması bağımsız değişkenler arasında çoklu bağlantılılığın olmadığını göstermektedir. Ayrıca Durbin-Watson katsayısı $(1,561)$ bağımsız değişkenler ile hata terimleri arasında sorunlu bir ilişkinin olmadığını göstermektedir. 
Tabloda yer alan bulgulara göre bağımsız değişkenlerin, bağımlı değişkeni açıklama düzeyi istatistiksel açıdan anlamlıdır $\left(R^{2}=, 502 \quad F=80,893 \quad p=, 000\right)$. Standardize edilmiş regresyon katsayılarına $(\beta)$ göre, bağımsız değişkenlerin bağımlı değişken üzerindeki göreceli önem sırası; etik lider, başarı, mutluluk ve merkezi şeklindedir. Regresyon katsayılarının anlamlılığına dair t-testi sonuçları incelendiğinde ise, materyalist eğilim alt boyutlarından başarı müşteriye yönelik KSS algısını pozitif yönde etkilerken, mutluluk ve merkeziliğin ise anlamlı bir etkiye sahip olmadığı görülmektedir. Etik liderlik algısının ise müşteriye yönelik KSS algısını pozitif yönde etkilediği tespit edilmiştir. Bu bilgiler doğrultusunda " $\mathrm{H} 1_{\mathrm{b}}$ : Etik liderlik davranışları işletmenin müşterilerine yönelik gerçekleştirdiği sosyal sorumluluk faaliyetleri algısını pozitif yönde etkiler" ve " $\mathrm{H} 2_{\mathrm{b}}$ : Çalışanların maddeyi başarı olarak görme eğilimi işletmenin müşterilerine yönelik gerçekleştirdiği sosyal sorumluluk faaliyetleri algısını pozitif yönde etkiler" hipotezleri kabul edilirken " $\mathrm{H} 3_{\mathrm{b}}$ : Çalışanların maddeyi hayatın merkezine koyma eğilimi işletmenin müşterilerine yönelik gerçekleştirdiği sosyal sorumluluk faaliyetleri algısını negatif yönde etkiler" ve " $\mathrm{H} 4_{\mathrm{b}}$ : Çalışanların maddi unsurlara sahip olmayı mutluluk kaynağı olarak görme eğilimi işletmenin müşterilerine yönelik gerçekleştirdiği sosyal sorumluluk faaliyetleri algısını negatif yönde etkiler" hipotezleri reddedilmiştir.

Tablo 4: Devlete Yönelik KSS Algısına Etki Eden Değişkenler

\begin{tabular}{|l|l|l|l|l|l|l|l|l|l|}
\hline Değişkenler & $\mathbf{B}$ & $\begin{array}{l}\text { Standart } \\
\text { Hata }\end{array}$ & $\boldsymbol{\beta}$ & $\mathbf{t}$ & $\mathbf{p}$ & $\mathbf{\text { Ikili r }}$ & $\begin{array}{l}\text { Kısmi } \\
\mathbf{r}\end{array}$ & Tol. & VIF \\
\hline (Sabit) & 1,986 &, 188 & - & 10,546 &, 000 & - & - & - & - \\
\hline MATBaşarı &, 118 &, 051 &, 158 & 2,320 &, 021 &, 349 &, 130 &, 442 & 2,263 \\
\hline MATMerkezi &,- 016 &, 060 &,- 019 &,- 265 &, 792 &, 230 &,- 015 &, 399 & 2,509 \\
\hline MATMutluluk &,- 149 &, 065 &,- 167 & $-2,315$ &, 021 &, 212 &,- 130 &, 390 & 2,565 \\
\hline Etik Lider &, 587 &, 054 &, 591 & 10,824 &, 000 &, 586 &, 522 &, 683 & 1,464 \\
\hline
\end{tabular}

Bağımsız değişkenler ile bağımlı değişken arasındaki ikili korelasyonlar incelendiğinde, materyalist eğilim alt boyutları ile pozitif ve düşük düzeyde ilişkilerin $(r=, 34,23,21)$ ve etik liderlik ile pozitif orta düzeyde $(r=, 58)$ bir ilişkinin olduğu görülmektedir. Diğer değişkenler kontrol edildiğinde ise tüm korelasyon katsayılarının düştüğü hatta materyalist eğilimin mutluluk alt boyutunun negatife dönüştüğü görülmektedir. Yine VIF değerleri arasında 10'dan yüksek bir değer ve tolerance değerleri arasında 0.20 'den düşük bir değer olmaması bağımsız değişkenler arasında çoklu bağlantılıı̆̆ın olmadığını göstermektedir. Ayrıca Durbin-Watson katsayısı $(1,630)$ bağımsız değişkenler ile hata terimleri arasında sorunlu bir ilişkinin olmadığını göstermektedir.

Tabloda yer alan bulgulara göre bağımsız değişkenlerin, bağımlı değişkeni açıklama düzeyi istatistiksel açıdan anlamlıdır $\left(R^{2}=, 353 \quad F=44,312 \quad p=, 000\right)$. Standardize edilmiş regresyon katsayılarına $(\beta)$ göre, bağımsız değişkenlerin bağımlı değişken üzerindeki göreceli önem sırası; etik liderlik, mutluluk, başarı ve merkezi şeklindedir. Regresyon katsayılarının anlamlılığına dair t-testi sonuçları incelendiğinde ise, materyalist eğilim alt boyutlarından başarı devlete yönelik KSS algısını pozitif yönde etkilerken, mutluluğun negatif yönde etkilediği ve merkeziliğin ise anlamlı bir etkiye sahip olmadığı görülmektedir. Etik liderlik algısının ise devlete yönelik KSS algısını pozitif yönde etkilediği tespit edilmiştir. Bu bilgiler doğrultusunda " $\mathrm{H} 1_{\mathrm{c}}$ : Etik liderlik davranışları işletmenin devlete yönelik gerçekleştirdiği sosyal sorumluluk faaliyetleri algısını pozitif yönde etkiler", "H2${ }_{\mathrm{c}}$ : Çalışanların maddeyi başarı olarak görme eğilimi işletmenin devlete yönelik gerçekleştirdiği sosyal sorumluluk faaliyetleri algısını pozitif yönde etkiler" ve "H4 c: Çalışanların maddi unsurlara sahip olmayı 
mutluluk kaynağı olarak görme eğilimi işletmenin devlete yönelik gerçekleştirdiği sosyal sorumluluk faaliyetleri algısını negatif yönde etkiler" hipotezleri kabul edilirken " $\mathrm{H} 3_{\mathrm{c}}$ : Çalışanların maddeyi hayatın merkezine koyma eğilimi işletmenin devlete yönelik gerçekleştirdiği sosyal sorumluluk faaliyetleri algısını negatif yönde etkiler" hipotezi reddedilmiştir.

Tablo 5: Topluma Yönelik KSS Algısına Etki Eden Değişkenler

\begin{tabular}{|l|l|l|l|l|l|l|l|l|l|}
\hline Değişkenler & $\mathbf{B}$ & $\begin{array}{l}\text { Standart } \\
\text { Hata } \mathbf{B}\end{array}$ & $\boldsymbol{\beta}$ & $\mathbf{t}$ & $\mathbf{p}$ & $\mathbf{\text { Íkili r }}$ & $\begin{array}{l}\text { Kısmi } \\
\mathbf{r}\end{array}$ & Tol. & VIF \\
\hline (Sabit) &, 986 &, 148 & - & 6,674 &, 000 & - & - & - & - \\
\hline MATBaşarı &, 102 &, 040 &, 139 & 2,558 &, 011 &, 489 &, 143 &, 442 & 2,263 \\
\hline MATMerkezi &, 021 &, 047 &, 026 &, 450 &, 653 &, 389 &, 025 &, 399 & 2,509 \\
\hline MATMutluluk &,- 060 &, 051 &,- 068 & $-1,181$ &, 239 &, 388 &,- 067 &, 390 & 2,565 \\
\hline Etik Lider &, 690 &, 043 &, 709 & 16,205 &, 000 &, 761 &, 675 &, 683 & 1,464 \\
\hline
\end{tabular}

Bağımsız değişkenler ile bağımlı değişken arasındaki ikili korelasyonlar incelendiğinde, materyalist eğilim alt boyutları ile pozitif ve düşük düzeyde ilişkilerin $(r=, 48,38,38)$ ve etik liderlik ile pozitif orta düzeyde $(r=, 76)$ bir ilişkinin olduğu görülmektedir. Diğer değişkenler kontrol edildiğinde ise tüm korelasyon katsayılarının düştüğü hatta materyalist eğilimin mutluluk alt boyutunun negatife dönüştüğü görülmektedir. Yine VIF değerleri arasında 10'dan yüksek bir değer ve tolerance değerleri arasında 0.20 'den düşük bir değer olmaması bağımsız değişkenler arasında çoklu bağlantılıı̆̆ın olmadığını göstermektedir. Ayrıca Durbin-Watson katsayısı $(1,832)$ bağımsız değişkenler ile hata terimleri arasında sorunlu bir ilişkinin olmadığını göstermektedir.

Tabloda yer alan bulgulara göre bağımsız değişkenlerin, bağımlı değişkeni açıklama düzeyi istatistiksel açıdan anlamlıdır $\left(R^{2}=, 586 \quad F=113,118 \quad p=, 000\right)$. Standardize edilmiş regresyon katsayılarına $(\beta)$ göre, bağımsız değişkenlerin bağımlı değişken üzerindeki göreceli önem sırası; etik lider, başarı, mutluluk ve merkezi şeklindedir. Regresyon katsayılarının anlamlılığına dair t-testi sonuçları incelendiğinde ise, materyalist eğilim alt boyutlarından başarı topluma yönelik KSS algısını pozitif yönde etkilerken, mutluluğun ve merkeziliğin ise anlamlı bir etkiye sahip olmadığı görülmektedir. Etik liderlik algısının ise topluma yönelik KSS algısını pozitif yönde etkilediği tespit edilmiştir. Bu bilgiler doğrultusunda " $\mathrm{H} 1_{\mathrm{d}}$ : Etik liderlik davranışları işletmenin topluma yönelik gerçekleştirdiği sosyal sorumluluk faaliyetleri algısını pozitif yönde etkiler" ve " $\mathrm{H} 2_{\mathrm{d}}$ : Çalışanların maddeyi başarı olarak görme eğilimi işletmenin topluma yönelik gerçekleştirdiği sosyal sorumluluk faaliyetleri algısını pozitif yönde etkiler" hipotezleri kabul edilirken " $\mathrm{H} 3_{\mathrm{d}}$ : Çalışanların maddeyi hayatın merkezine koyma eğilimi işletmenin topluma yönelik gerçekleştirdiği sosyal sorumluluk faaliyetleri algısını negatif yönde etkiler" ve "H4 $4_{d}$ : Çalışanların maddi unsurlara sahip olmayı mutluluk kaynağı olarak görme eğilimi işletmenin topluma yönelik gerçekleştirdiği sosyal sorumluluk faaliyetleri algısını negatif yönde etkiler" hipotezleri reddedilmiştir.

\section{Sonuç ve Tartışma}

Birinci Dünya Savaşı sonrasının çevreyi önemsemeyen, verimlilik odaklı ve otoriter insanı zaman içinde geçerliliğini yitirmeye başlamıştır. Hawthorne araştırmaları sonrası birçok bilim dalında ve özellikle işletme alanında insanın ön plana çıkartıldığı bir döneme geçiş sağlanmıştır. Ancak yaşanan teknolojik gelişmeler, fabrikalaşmanın ve dolayısıyla seri üretimin artışı, tüketici talep ve beklentilerindeki ölçülemeyen değişim işletmeleri daha dikkatli olmaya sevk etmiştir. Sadece devlete karşı yasal düzeydeki 
sorumlulukların yerine getirilmesi gereken dönemden müşterilere, çalışanlara, sivil toplum kuruluşlarına, rakiplere ve topluma karşı sorumluluklara da önem verilmesi gereken bir döneme geçiş yapılmıştır. Dolayısıyla mekanik yapıdan organik yapıya geçiş konusu tercih olmaktan çıkmış ve dış çevre unsurlarının da hesaba katılarak stratejik planların yapıldığı proaktif bir örgüt yapısı bugünün işletmeleri için zorunluluk halini almıştır. Özellikle talep esnekliğinin yüksek olduğu turizm sektörü ve özelde otel işletmeleri için dış çevrenin istek ve arzularını takip etmek, bunlara cevap verici faaliyetlerde bulunmak, doğal çevreyi koruyucu ve geliştirici etkinlikler düzenlemek rekabet avantajı kazanmada önemli bir hal almıştır. Bu bağlamda yapılan araştırma kapsamında öncelikle otel işletmelerinin gerçekleştirdiği sosyal sorumluluk faaliyetlerine yönelik algıya etki edecek iki değişken belirlenmiştir. Bireysel düzeyde çalışanların materyalist eğilimleri, örgüt düzeyinde ise yöneticilerin etik liderlik davranışları ve aralarındaki etkileşimler ele alınmıştır.

Elde edilen sonuçlara göre etik liderlik davranışlarının KSS'nin dört alt boyutuna yönelik algıda da pozitif ve yüksek düzeyde etkilere sahip olduğu görülmektedir. Adil ve güvenilir davranışlar sergileyen, etik standartlar belirleyip bu standartları yaşamıyla rol model olarak çalışanlarına aktaran liderlik davranışlarının çalışanların kendi işletmelerinin sosyal sorumluluk faaliyetlerini pozitif algılaması ve değerlendirmesinde önemli etkiye sahip olduğu tespit edilmiştir. Carroll (1991) benzer şekilde KSS piramidinde üçüncü aşamanın etik sorumluluklarla dolu olduğunu, liderin çalışanları ile karşılıklı güven ve inanca dayalı katılımcı bir liderlik tarzı geliştirmesi gerektiğini, adilliğin ön planda olduğu ve çalışanların her türlü hakkının savunulduğu bir işletme ortamı oluşturması gerektiğini vurgulamaktadır. De Hoogh ve Den Hartog (2008) liderin sosyal sorumluluk algısının etik liderlik ile ilişkili olduğunu ve özellikle liderin etik standart belirleyici yönünün önem arz ettiğini belirtmektedir. Groves ve LaRocca (2011) liderin; organizasyonun ve topluluğun iyileştirilmesi için tüm tarafların kişisel çıkarlarının ötesine bakmaları konusunda ilham verirken, çok sayıda paydaşın ilgisini açıkça ortaya koyan kolektif bir vizyonun geliştirilmesi gerektiğini de vurgulamaktadır.

Elde edilen diğer bir sonuca göre materyalist eğilimin alt boyutlarından başarıyı maddi unsurlarla belirleme değişkeninin KSS'nin dört alt boyutuna yönelik algıda da pozitif etkilere sahip olduğu görülmektedir. Baştürk (2013) materyalizm algısının zaman içinde ekonomik ve fiziksel güvenliğe öncelik veren formdan; özgürlük, kendini ifade etme ve hayat kalitesine öncelik veren post-materyalist değerlere dönüştüğünü ifade etmektedir. Başarıya ulaşmış bireylerin yeni olasılıklara daha açık olmasına bağlı olarak postmodern değişimin etkilerinden daha çok etkilenmiş olmaları beklentisiyle postmodern değerler ile başarı arasında olumsuz değil tam aksine olumlu bir ilişkinin olması beklentisini doğurmaktadır (Özgüngör, 2009). İçinde bulunduğumuz popüler kültür çocukları ve gençleri mutluluğu, başarıyı elde etme ve kendini gerçekleştirme yolunda maddi ürünlere odaklamaktadır (John, 1999). Materyalist düşünceye sahip bireyler kendi ya da diğerlerinin başarılarını elde edilen maddi varlıkların sayısı ve kalitesine bağlamaktadır (Richins ve Dawson, 1992). Çalışanlarda işletmelerinin KSS alanında ön plana çıkması, pozitif imaj oluşturması, şirketin rakiplerine kıyasla rekabet avantajı kazanması gibi başarılı hamlelerde bulunmasını kendi kazanç ve başarıları gibi algılamaları sonucu KSS uygulamalarına yönelik pozitif bir algı geliştirdikleri söylenebilir.

Diğer bir sonuca göre materyalist eğilimin alt boyutlarından hayatının merkezine maddi unsurları koyma değişkeninin KSS'nin dört alt boyutuna yönelik algıya bir etkisi olmadığı ortaya çıkmıştır. Bireyin maddi nesnelerin elde edilmesi ve sahip olunmasına yönelik geliştirdiği değer algısı (Çopur, 2011) olarak materyalizm, bireyin hayatındaki tüm gelişmeleri yorumlamasında ve anlamlandırmasında etkili hale geldiğinde çalıştığı 
kurumun KSS faaliyetlerine yönelik algısında bir etkiye sahip olmadığı düşünülmektedir. Bununla birlikte materyalist eğilimin alt boyutlarından mutluluğu elde edilen maddi unsurlarla açıklama değişkeninin çalışan ve devlete yönelik KSS algısına negatif yönde etki ettiği tespit edilmiştir. Kasser ve Ahuvia (2002) güçlü içselleştirilmiş materyalistik değerlere sahip olan bireylerin canlılıklarını ve mutluluklarını kaybettiğini ve kaygı düzeylerinin yükseldiğini belirtmektedir. Ryan ve Dziurawiec (2000) ise materyalistik düşünceye sahip bireylerin yaşam doyumunun ve hayat standartlarına yönelik algılarının düşük düzeyde olduğunu belirtmektedir. Roberts ve Clement (2006) ise maddi unsurlarla mutlu olma değişkeninin sağlık, arkadaş, aile veya eğlence gibi yaşam tatmininin boyutları ile negatif korelasyonlara sahip olduğunu belirtmektedir. Dolayısıyla maddi unsurlara ve bunların sahipliğine odaklanarak mutluluk arayışında olan bireylerin dış çevre unsurlarını dikkate almadığını belirtebiliriz. Gerçekleştirilen KSS faaliyetlerinin kendilerine maddi bir fayda sağlamayacağı yönünde bir algı oluştuğunda çalışanların gerek kendilerine gerek devlete yönelik gerçekleştirilen sosyal sorumluluk faaliyetlerini de olumsuz algıladığı söylenebilir.

KSS faaliyetlerine yönelik algıya en önemli etkiye sahip değişkenin etik liderlik olması nedeniyle etik iklim, etik kültür veya işletme içi kullanılan iletişim türleri gibi değişkenler üzerinden KSS faaliyetlerine yönelik algı geliştirilebilir. Ayrıca KSS faaliyetlerinin karlıı̆ga ve verimliliğe etkisi ortaya konularak materyalist bireylerin KSS algısı pozitif yönde geliştirilebilir. Bununla birlikte işletme içi ödüllendirme sisteminin intiyaç duyulan maddi unsurlar üzerinden sağlanması çalışan motivasyonunu da pekiştirebilir.

\section{Kaynakça}

Altunışık, R., Coşkun, R., Bayraktaroğlu, S., Yıldırım, E. (2007). Sosyal Bilimlerde Araştırma Yöntemleri-SPSS Uygulamalı, 5. Baskı, Sakarya: Sakarya Yayıncılık.

Ahuvia, A.C. ve Wong, N.Y. (2002). "Personality and Values Based Materialism: Their Relationship and Origins". Journal of Consumer Psychology, 12(4), 389-402.

Aronson, E. (2001). "Integrating Leadership Styles and Ethical Perspectives". Canadian Journal of Administrative Sciences, 18(4), 244-256.

Baştürk, S. (2013). Değer Dönüşümünün Paradoksları: Post-materyalist Çalışma Yönelimlerinin Eleştirisi. İş Ahlakı Dergisi, 6(2), 9-53.

Belk, R.W. (1985). "Materialism: Trait Aspects of Living in the Material World". Journal of Consumer Research, 12(3), 265-280.

Belk, R.W. (1984), "Three Scales to Measure Constructs Related to Materialism: Reliability, Validity, and Relationships to Measures of Happiness", in NA Advances in Consumer Research, Vol.11, eds. Thomas C. Kinnear, Provo, UT: Association for Consumer Research, 291-297.

Belk, R.W. (1983), "Worldly Possessions: Issues and Criticisms," in Advances in Consumer Research, Vol.10, ed. Richard P. Bagozzi and Alice M. Tybout, Ann Arbor, MI: Association for Consumer Research, 514-519.

Boğan, E. ve Dedeoğlu, B.B. (2017). "The Link between Perceived Corporate Social Responsibility, Commitment to the Tourism Industry and Willigness to Recommend the Organization", 7th Advances in Hospitality \& Tourism Marketing and Management (AHTMM) Conference, Fagamusta, Cyprus.

Boğan, E., Ulama, Ş. ve Sarışık, M. (2016). "Zincir Ve Grup Otel İşletmelerinin Kurumsal Sosyal Sorumluluk Faaliyetlerini Duyurmada Web Sitelerinin Etkinliği Üzerine Bir Araştırma: Türkiye Örneği", International Conference on Eurasian Economies, Kaposvar, Hungary. 
Brammer, S., Millington, A. ve Rayton, B. (2007). "The Contribution of Corporate Social Responsibility to Organizational Commitment". International Journal of Human Resource Management, 18: 1701-1719.

Brook, P. (2013). "Emotional Labour and the Living Personality at Work: Labour Power, Materialist Subjectivity and the Dialogical Self". Culture and Organization, 19(4), 332-352.

Brown, M.E., Treviño, L.K. ve Harrison, D.A. (2005).“Ethical Leadership: A Social Learning Perspective for Construct Development and Testing", Organizational Behavior and Human Decision Processes, 97(2), 117-134.

Carroll, A.B. (1979). "A Three-Dimensional Conceptual Model of Corporate Performance", Academy of Management Review, 4(4), 497-505.

Carroll, A.B. (1991). "The Pyramid of Corporate Social Responsibility: Toward the Moral Management of Organizational Stakeholders", Business Horizons, 34(4), 39-48.

Carroll, A.B. (1999). "Corporate Social Responsibility Evolution of A Definitional Construct". Business \& Society, 38(3), 68-295.

Commission of the European Communities (2001).Green Paper: Promoting a European Framework for Corporate Social Responsibility, No. 366, Brussels, http://europa eu.int

Conaway, R.N. ve Fernandez, T.L. (2000). "Ethical Preferences among Business Leaders: Implications for Business Schools". Business Communication Quarterly, 63(1), 23-31.

Cowper-Smith, A., De Grosbois, D. (2011). "The Adoption of Corporate Social Responsibility Practices in the Airline Industry", Journal of Sustainable Tourism, 19(1), 59-77.

Çakmakçı, E. (2012). "Bilgi Teknolojisi Kullanımının Otel Performansı Ve Verimliliğine Etkisi". Verimlilik Dergisi, 4, 47-66.

Çalıșkan, O. ve Ünüsan, Ç. (2011). "Hotel Employee Perceptions of Corporate Social Responsibility and Its Effects on Job Satisfaction and Intention to Stay". Anatolia: Turizm Arastirmalari Dergisi, 22(2), 154-166.

Çelik, S., Dedeoğlu, B.B. ve İnanır, A. (2015). "Relationship Between Ethical Leadership, Organizational Commitment and Job Satisfaction at Hotel Organizations". Ege Akademik Bakis, 15(1), 53-63.

Çopur, Z. (2011). "Effects of Financial Socialization and Perceived Norms on Materialism: College Students Sample". Journal of Family and Economic Issues, 32(4), 1-20.

Dahlsrud, A. (2008). "How Corporate Social Responsibility is Defined: An Analysis of 37 Definitions", Corporate Social Responsibility and Environmental Management, 15(1), 1-13.

De Hoogh, A.H. ve Den Hartog, D.N. (2008). Ethical and Despotic Leadership, Relationships with Leader's Social Responsibility, Top Management Team Effectiveness and Subordinates' Optimism: A Multi-Method Study. The Leadership Quarterly, 19(3), 297-311.

De Roeck, K. ve Farooq, O. (2018). "Corporate Social Responsibility and Ethical Leadership: Investigating Their Interactive Effect on Employees' Socially Responsible Behaviors". Journal of Business Ethics, 151(4), 923-939.

Doğan, S.Y. (2010). "Materyalist Eğilimlerin Demografik Özelliklere Göre Farklılaşmasına Yönelik Bir Araştırma", C.Ü. Iktisadi ve Idari Bilimler Dergisi, 11(1), 57-70.

Du, S., Swaen, V., Lindgreen, A. ve Sen, S. (2013). "The Roles of Leadership Styles in Corporate Social Responsibility". Journal of Business Ethics, 114(1), 155-169. 
Engelbrecht, A.S., Heine, G. ve Mahembe, B. (2017). "Integrity, Ethical Leadership, Trust and Work Engagement". Leadership \& Organization Development Journal, 38(3), 368-379.

Erdem, B. (2004). "Otel İşletmelerinde İnsan Kaynakları Planlamasının Yeri Ve Önemi”. ISGUC The Journal of Industrial Relations and Human Resources, 6(1), 35-54.

Farooq, M., Farooq, O. ve Jasimuddin, S.M. (2014). "Employees Response to Corporate Social Responsibility: Exploring the Role of Employees' Collectivist Orientation", European Management Journal, 32(6), 916-927.

Freeman, R.E. (1984). Strategic Management: A Stakeholder Approach, Cambridge University Press, New York.

Fu, H., Ye, B.H. ve Law, R. (2014). "You Do Well and I Do Well? The Behavioral Consequences of Corporate Social Responsibility". International Journal of Hospitality Management, 40, 62-70.

George, D. ve Mallery, M. (2010). SPSS for Windows Step by Step: A Simple Guide and Reference, 17.0 update (10a ed.) Boston: Pearson

Giacalone, R. A., Jurkiewicz, C. L. ve Deckop, J. R. (2008). "On Ethics and Social Responsibility: The Impact of Materialism, Postmaterialism, and Hope". Human Relations, 61(4), 483-514.

Giacalone, R. A. ve Thompson, K. R. (2006). "Business Ethics and Social Responsibility Education: Shifting The Worldview". Academy of Management Learning \& Education, 5(3), 266-277.

Godfrey, P.C., Merrill, C.B. ve Hansen, J.M. (2009). "The Relationship Between Corporate Social Responsibility and Shareholder Value: An Empirical Test of the Risk Management Hypothesis". Strategic Management Journal, 30(4), 425-445.

Groves, K.S. ve LaRocca, M.A. (2011). "An Empirical Study of Leader Ethical Values, Transformational and Transactional Leadership, and Follower Attitudes Toward Corporate Social Responsibility". Journal of Business Ethics, 103(4), 511-528.

Hirsh, J.B. ve Dolderman, D. (2007). "Personality Predictors of Consumerism and Environmentalism: A Preliminary Study". Personality and Individual Differences, 43(6), 1583-1593.

John, D. R. (1999). Consumer Socalization of Children: A Retrospective Look atTwenty-Five Years of Research. Journal of Consumer Research, 26 (December), 183-213.

Kang, K.H., Lee, S. ve Huh, C. (2010). "Impacts of Positive and Negative Corporate Social Responsibility Activities on Company Performance in the Hospitality Industry". International Journal of Hospitality Management, 29(1), 72-82.

Kasser, T. ve Ahuvia, A. (2002). "Materialistic Values and Well-Being in Business Students". European Journal of Social Psychology, 32(1), 137-146.

Kim, E. ve Ham, S. (2016). "Restaurants' Disclosure of Nutritional Information as A Corporate Social Responsibility Initiative: Customers' Attitudinal and Behavioral Responses." International Journal of Hospitality Management, 55, 96-106.

Kim, H.L., Rhou, Y., Uysal, M. ve Kwon, N. (2017). "An Examination of the Links between Corporate Social Responsibility (CSR) and Its Internal Consequences". International Journal of Hospitality Management, 61, 26-34.

Kim, J.S., Song, H.J. ve Lee, C.K. (2016). "Effects of Corporate Social Responsibility and Internal Marketing on Organizational Commitment and Turnover Intentions". International Journal of Hospitality Management, 55, 25-32.

Kolodinsky, R. W., Madden, T. M., Zisk, D. S. ve Henkel, E. T. (2010). "Attitudes About Corporate Social Responsibility: Business Student Predictors". Journal of Business Ethics, 91(2), 167-181. 
Kucukusta, D., Mak, A. ve Chan, X. (2013). "Corporate Social Responsibility Practices in Four and Five-Star Hotels: Perspectives from Hong Kong Visitors". International Journal of Hospitality Management, 34, 19-30.

Küçüksille, E. (2010). Çoklu Doğrusal Regresyon Modeli içinde Ş. Kalaycı (Ed.), SPPS Uygulamalı Çok Değişkenli İstatistik Teknikleri, 5. Baskı, Ankara: Asil Yayın Dağıtım.

Lawton, A. ve Páez, I. (2014). Developing A Framework for Ethical Leadership. Journal of Business Ethics, 130(3), 639-649.

Lee, S., Seo, K. ve Sharma, A. (2013). "Corporate Social Responsibility and Firm Performance in the Airline Industry: The Moderating Role of Oil Prices". Tourism Management, 38, 20-30.

Lee, S., Singal, M. ve Kang, K.H. (2013). "The Corporate Social ResponsibilityFinancial Performance Link in the US Restaurant Industry: Do Economic Conditions Matter?". International Journal of Hospitality Management, 32, 2-10.

Lin, C.P. ve Liu, M.L. (2017). "Examining the Effects of Corporate Social Responsibility and Ethical Leadership on Turnover Intention". Personnel Review, 46(3), 526550.

Martínez, P., Pérez, A. ve Rodríguez del Bosque, I. (2013). "Measuring Corporate Social Responsibility in Tourism: Development and Validation of An Efficient Measurement Scale in the Hospitality Industry", Journal of Travel \& Tourism Marketing, 30(4), 365-385.

Mattingly, J.E. ve Berman, S.L. (2006). "Measurement of Corporate Social Action Discovering Taxonomy in the Kinder Lydenburg Domini Ratings Data". Business \& Society, 45(1), 20-46.

McKeage, K.K.R., Richins, M.L. ve Debevec, K. (1993). "Self-Gifts and the Manifestation of Material Values".Advances in Consumer Research, Vol.20, 359364.

McKendrick, N., Brewer, J. ve Plumb, J.H. (1982).The Birth of a Consumer Society: The Commercialization of Eighteenth Century England, London: Europa Publications Limited.

Özdemir, G. (2015). Zincir Otel İşletmesi Çalışanlarının Sigara İ̧me Alışkanlığının Kurum Üzerindeki Etkilerinin Değerlendirilmesi: Ankara Örneği. İstanbul Üniversitesi, Sosyal Bilimler Enstitüsü, Çalışma Ekonomisi ve Endüstri İlişkileri ABD: İstanbul.

Özgüngör, S. (2009). Postmodern Değerler, Kimlik Oluşumu Ve Yaşam Doyumu. Türk Psikolojik Danışma ve Rehberlik Dergisi, 4(31), 32-42.

Park, S.Y. ve Levy, S.E.(2014). "Corporate Social Responsibility: Perspectives of Hotel Frontline Employees", International Journal of Contemporary Hospitality Management, 26(3), 332-348.

Pelit, E. ve Öztürk, Y. (2010). "Otel İşletmeleri İşgörenlerinin İş Doyum Düzeyleri: Sayfiye Ve Şehir Otel İşletmeleri İ̧̧görenleri Üzerinde Bir Araştırma". Işletme Araştırmaları Dergisi, 2(1), 43-72.

Piccolo, R.F., Greenbaum, R., Den Hartog, D.N. ve Folger,R. (2010). "The Relationship Between Ethical Leadership andCore Job Characteristics". Journal of Organizational Behavior,31, 259-278.

Quadir, S.E. (2012). "Materyalistik Değerlerin Gelişiminde Tüketici Sosyalizasyonunun Rolü". Eğitim ve Insani Bilimler Dergisi, 3(6), 31-50.

Richins, M.L. (2004). "The Material Values Scale: Measurement Properties and Development of a Short Form". Journal of Consumer Research, 31(1), 209-219.

Richins, M.L. ve Dawson, S. (1992). "A Consumer Values Orientation for Materalism and Its Measurement: Scale Development and Validation", Journal of Consumer Research, 19(3), 303-316. 
Roberts, J. A. ve Clement, A. (2007). "Materialism and Satisfaction with Over-All Quality of Life and Eight Life Domains". Social Indicators Research, 82(1), 7992.

Rupp, D.E. ve Mallory, D.B. (2015). "Corporate Social Responsibility: Psychological, Person-centric, and Progressing". The Annual Review of Organizational Psychology and Organizational Behavior, 2, 211-236.

Ryan, L. ve Dziurawiec, S. (2001). "Materialism and its Relationship to Life Satisfaction". Social Indicators Research, 55(2), 185-197.

Sevin, D. H. ve Küçük S. (2016). "İşgörenlerin Rekreasyonel Etkinliklere Katılım Düzeyleri İle Çalışma Performansları Arasındaki İlişkiyi Belirlemeye Yönelik Bir Araştırma". Journal of Recreation and Tourism Research, 3(1), 24-31.

Siu, N.Y.M., Zhang, T.J.F. ve Kwan, H.Y. (2014). "Effect of Corporate Social Responsibility, Customer Attribution and Prior Expectation on Post-Recovery Satisfaction." International Journal of Hospitality Management, 43, 87-97.

TDK (Türk Dil Kurumu), "Maddecilik", http://www.tdk.gov.tr, 18.09.2017.

Trevino, L.K., Hartman, L.P. ve Brown, M. (2000).“Moral Person and Moral Manager: How Executives Develop aReputation for Ethical Leadership".California Management Review, 42(4), 128-142.

Türker, D. (2006). The Impact of Employee Perception of Corporate Social Responsibility on Organizational Commitment: A Scale Development Study. Yüksek Lisans Tezi. Dokuz Eylül Üniversitesi, Sosyal Bilimler Enstitüsü, İşletme ABD, İzmir.

Türker, D. (2009). "Measuring Corporate Social Responsibility: A Scale Development Study", Journal of Business Ethics, 85(4), 411-427.

Van Den Akker, L., Heres, L., Lasthuizen, K. ve Six, F. (2009).“Ethical Leadership and Trust: It's All About Meeting Expectations".International Journal of Leadership Studies, 5(2), 102-122.

Wang, C.J. (2014). "Do Ethical and Sustainable Practices Matter? Effects of Corporate Citizenship on Business Performance in the Hospitality Industry". International Journal of Contemporary Hospitality Management, 26(6), 930-947.

Watson, J.J. (2003)."The Relationship of Materialism to Spending Tendencies, Saving, and Debt". Journal of Economic Psychology, Vol.24, 723-739.

World Business Council for Sustainable Development (WBCSD). (1999). "Corporate Social Responsibility: Meeting Changing Expectations", Cenevre.

Yanıklar, C. (2010). "Tüketim Kültürü, Kapitalizm ve İnsan İhtiyaçları Arasındaki İlişki Üzerine Bir Tartışma”. C.Ü. Sosyal Bilimler Dergisi, 34(1), 25-32.

Yazıcıoğlu, Y. ve Erdoğan, S. (2007). SPSS Uygulamalı Bilimsel Araştırma Yöntemleri. 2. Baskı, Ankara: Detay Yayıncılık.

Youn, H., Hua, N. ve Lee, S. (2015). "Does Size Matter? Corporate Social Responsibility and Firm Performance in the Restaurant Industry". International Journal of Hospitality Management, 51, 127-134.

Yüce, Y. (2009). Hilmi Ziya Ülken'in Materyalizm ve Spiritualizme Eleştirel Yaklaşımı. Selçuk Üniversitesi, Sosyal Bilimler Estitüsü, Felsefe ve Din Bilimleri Anabilim Dalı: Konya.

Zientara, P., Kujawski, L. ve Bohdanowicz-Godfrey, P. (2015). "Corporate Social Responsibility and Employee Attitudes: Evidence from A Study of Polish Hotel Employees". Journal of Sustainable Tourism, 23(6), 859-880. 